\title{
Demographic transition and population ageing in Yogyakarta
}

\author{
Muhammad Arif Fahrudin Alfana ${ }^{1}$, Rizky Laudiansyah ${ }^{1}$, Navila Ulfi Fauziyanti ${ }^{1}$, Mohammad Isnaini Sadali ${ }^{2}$, Novia \\ Ismayuni $^{1}$, and Rivo Maulana ${ }^{1}$ \\ ${ }^{1}$ Department of Environmental Geography, Faculty of Geography, Universitas Gadjah Mada, Indonesia \\ ${ }^{2}$ Department of Development Geography, Faculty of Geography, Universitas Gadjah Mada, Indonesia
}

\begin{abstract}
The aim of this research were to explain the demographic transition and the population ageing in the Special Region of Yogyakarta (DIY). This study used previous demographic and profiles of the elderly data in DIY. These data collected from the Central Bureau of Statistics Indonesia (BPS) and other relevant institutions, and then analyzed by descriptive analysis. The results showed The Special Region of Yogyakarta's demographic transition is in its final stages. This is due to the population ageing in this region; which indicated by high percentage of elderly population. Population ageing in DIY has been happening since 1990. In 1990, the percentage of the elderly population was $11,3 \%$ and became $14,37 \%$ in 2019 .
\end{abstract}

\section{Introduction}

The demographic transition, population ageing, and the elderly are interested to discuss and comprehensive studies. Mostly, The demographic transition caused by the population ageing and it happened faster than before [1]. It implies that soon the world will become more elderly people than middle-aged. Therefore, population policy is needed for the elderly in the future to live their lives with a decent quality of life $[2,3]$. This is also closely related to the availability of human resources in the future.

In the most cases, developed countries are in the final transition period [1]. Meanwhile, developing countries are having different transition stages in each countries because of their unique demographic process. In this condition, Indonesia generally has a demographic transition period with a rapid population ageing process [4]. Indonesia in 2030 was already in the population ageing, which the percentage of its elderly population reached $14,1 \%$ of the total population [4].

Studies on the demographic transition, population ageing and the elderly population in (The Special Region of Yogyakarta) DIY are very interesting to be discussed. The high percentage of elderly population in DIY is one of the most powerful evidence that the demographic transition in DIY is in its final stages. The process of population ageing in DIY allegedly has happened a long time ago. It is indicated by the percentage of elderly over $7-10 \%$ [4]. According to population census data 1990, DIY had $11,3 \%$ of elderly people $[5,6]$. Besides, these issues will become one of the strategic issues for the DIY government to improve demographic development.
This study describes the period of each demographic transition in DIY. It shows an overview of current demographic stage and explains the transformation of population ageing in DIY. This information as an input in future population development and planning. Based of this condition, this study try to figure out how the demographic transition process is in DIY. The purpose of this study is to explain the demographic transition process and population ageing in DIY.

\section{Data and Method}

This research is a quantitative and analyzed by descriptive analysis. DIY choosen as study area that analyzed in provincial level. The research discussed about the demographic transition in 1980-2010 and population ageing process in the last 10 years.

The main data is secondary data that collected from Central Bureau of Statistics Indonesia (BPS) and supporting data from other relevant institutions. These are following data that arranged this research:

1. Demographic transition data is formulated from the DIY's total population based on age and sex of the population in 1980-2010 and value of Total Fertility Rate (TFR), Crude Birth Rate (CBR), Crude Death Rate (CDR), Infant Mortality Rate (IMR), and Under-five Mortality Rate (U5MR).

2. Population ageing data from BPS publication about elderly profile in 2009-2019.

\footnotetext{
* Corresponding author: arif.fahrudin@ugm.ac.id
} 


\section{Result and Discussion}

\subsection{Demographic Transition in The Special Region of Yogyakarta}

Demographic transition is defined as a transformation in demographic process in a region. Demographic transition has four stages, which the last stage has low fertility and mortality. The demographic transition stage itself can be indicated by transformation of population pyramid. The first stage of the demographic transition has an expansive pyramid and the final stage turns to constructive pyramid [7].

DIY is one of earlier region that completed the demographic transition than other provinces in Indonesia [8]. This is proven by the low number of mortality and fertility. One indicator of fertility aspects is the TFR with 2,2 and CBR with 14,2 [9,10]. Other supporting data was the aspect of mortality. It shows low number of IMR, Maternal Mortality Rate (MMR), CDR and high life expectancy.

The demographic transition that happens in DIY also shown by population pyramid. In 1980 it was early stationary pyramid that refers decreasing in fertility rates (Figure 1). The pyramid turned to have a shorter side the on 0-4-year-old than 5-9 years old pyramid side. DIY mortality conditions also increased. This is indicated by the high life expectancy (the pyramid side of the 75+ age's higher than the young age). According to those conditions, the stage of demographic transition in 1980 has already at the third or fourth stage in DIY.

In 1990, there was transformation of population pyramid. DIY birth rates became lower than ten years ago. TFR as one of the indicators of fertility. The value of TFR in DIY reduced from 3,42 in 1980 to 2,08 in 1990. The mortality condition in DIY also decreased. It shown by increasing life expectancy (from 62 to 67 years), a lower value in IMR (from 62 to 42 deaths per 1000 live births) and diminised in U5MR (from 85 to 54 deaths per 1000 live births).

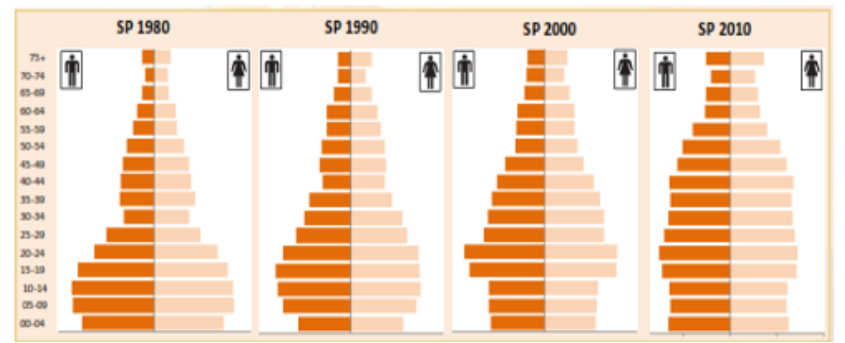

Fig. 1. DIY’s Population Pyramid in 1980-2010 [11]

The shape of DIY's population pyramid changed in 2000. Birth and death rate became lower. DIY birth rate in 2000 was the lowest value in 1971-2010. TFR value was 1,44 based on the BPS of DIY. The mortality rate in DIY was decreasing according to the indicator of IMR and U5MR.

In 2010, the population pyramid also changed. The birth rate has increased based on by TFR indicator. The value of DIY's TFR is 1,93. The value is estimated to increase in 2017. The SDKI shows a TFR value of 2.2. Based on indicators of IMR and U5MR, it shows that the birth rate has increased and the mortality rate has decreased. The IMR in DIY in 2010 was 17 per 1000 live births and the U5MR was also 17 per 1000 live births. In the 2010-2015, the fertility rate increased [10], and indicators of IMR and U5MR became lower in DIY.

The demographic transition in DIY transformed in 1980-2010. The fertility rate in DIY quickly decreased in 1980-2000 and then increased after 2000. Moreover, the IMR indicator and the U5MR continuosly decreasing (Figure 2). This trend has the same as Indonesia's. This is commonly happened because reducing of fertility is going faster than mortality [12]. The similar trend is projected to 2025 for Indonesia and DIY.

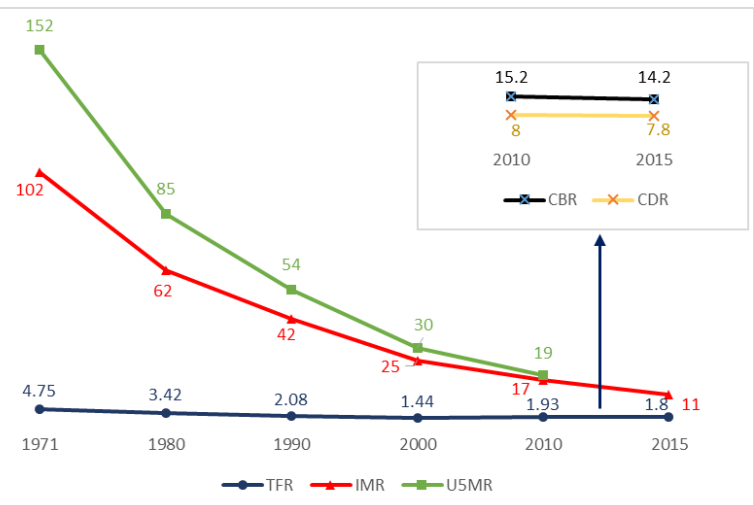

Fig. 2. Demographic Trantition of DIY based on TFR, IMR, and U5MR $[5,9,11,13,14]$

Tranformation demographic transition in DIY was related with epidemiological transition. As demographic transition in final stage, the epidemiological transition also in its final stage. One of characteristics was value of mortality decreased and life expectancy estimated at greater than or equal to 50 years [15]. The CDR value was diminished and the life expectancy in 1971 was 53 years and in 2015 was 75 years (See Figure 3). And also there was transition from infectious to degenerative diseases. In 2011-2017 the percentage of degenerative diseases increased, while infectious diseases tended to decrease [16].

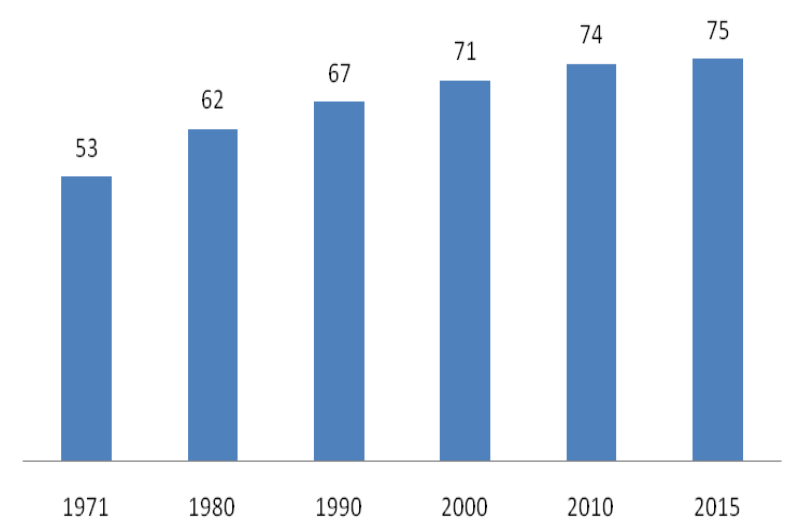

Fig. 3. DIY's Life Expectancy in 1971-2015 [5,10,13,14] 


\subsection{Population ageing in the Special Region of Yogyakarta}

Population ageing is strategic issues in DIY related to the demographic transition. Population ageing itself is caused by a transformation in the age structure of the population due to the demographic process of birth, death, and migration [17]. The decreasing in birth rate has implicate to increase population ageing. These phenomenon show high percentage of the elderly. The high percentage of elderly is the main indicator that the ageing process of the population has happened.

The phenomenon of population ageing in DIY has been happening since 1990. At that time, the percentage of the elderly was $11.3 \%$. Moreover, the percentage of elderly in 1990 was higher than the percentage of Indonesian elderly in the projection for 2020. Based on BPS data, the percentage of Indonesian elderly in 2020 is estimated at $10.2 \%$ [4]. This means that DIY has higher percentage of the elderly than the national's.

According to BPS; Indonesian elderly population statistics 2019, the proportion of elderly people in DIY reached $14.5 \%$ [18]. Not only DIY, but some provinces llike Central Java, East Java, Bali and North Sulawesi had similar value (See Figure 4). The proportion of elderly in DIY in 2019 was higher than the projection of Indonesian elderly in 2030. In 2030 the proportion of elderly in Indonesia will reach $14.1 \%$ and at that time Indonesia will be in the stage of "old population" [4]. This shows that the proportion of elderly in Yogyakarta have greater than or equal to $14.1 \%$ and has entered the final population stage in 2019.

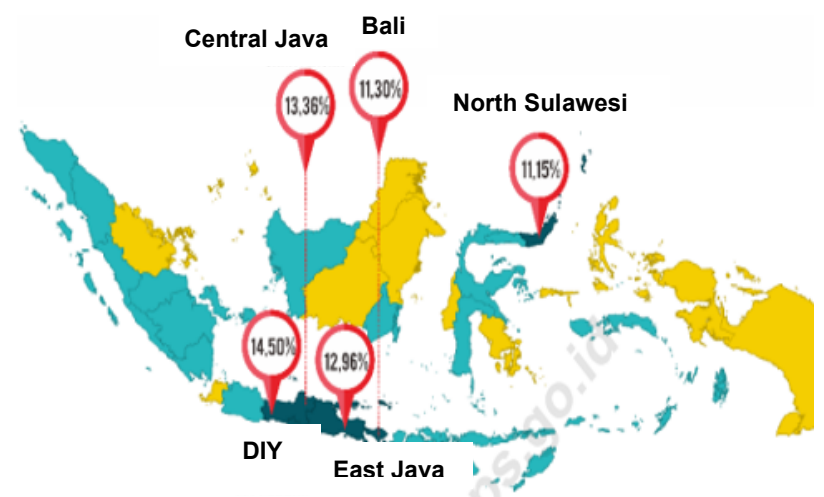

Fig. 4. Top Five Provinces of Older People Percentage in Indonesia [18]

Population ageing in DIY has been happening since 1990. This was indicated by the rate of the elderly which already more than $10 \%$. This value has been continuously increasing. According to BPS publication; DIY in Figures 2020, the percentage of elderly people in DIY is 14.37 [19]. And this percentage is likely to increase in the following years. The percentage of elderly in DIY from 1990-2019 can be seen in table 1.
Table 1. Percentage of Elderly in Special Region of Yogyakarta 1990-2019 [5,6,19,20,21,22]

\begin{tabular}{|c|c|c|c|c|c|c|}
\hline \multirow{2}{*}{$\begin{array}{c}\text { Age } \\
\text { Group }\end{array}$} & $\mathbf{1 9 9 0}$ & $\mathbf{2 0 0 0}$ & $\mathbf{2 0 0 5}$ & $\mathbf{2 0 1 0}$ & $\mathbf{2 0 1 5}$ & $\mathbf{2 0 1 9}$ \\
\cline { 2 - 7 } & 3.78 & 3.95 & 3.62 & 3.69 & 4.15 & 4.78 \\
\hline $\mathbf{6 0 - 6 4}$ & 2.77 & 3.13 & 3.31 & 3.15 & 3.09 & 3.47 \\
\hline $\mathbf{6 5 - 6 9}$ & 2.10 & 2.61 & 2.61 & 2.72 & 2.43 & 2.46 \\
\hline $\mathbf{7 0 - 7 4}$ & 2.48 & 2.70 & 3.32 & 3.56 & 3.70 & 3.65 \\
\hline $\mathbf{7 5 +}$ & 11.13 & 12.48 & 12.48 & 13.12 & 13.38 & 14.37 \\
\hline TOTAL & & & &
\end{tabular}

\subsection{The Challenges of Yogyakarta's Human Resources in the Future}

Yogyakarta is the only province in Indonesia that reaches the final stage of demographic transistion [4]. The number and percentage of the elderly population in DIY also increase by the time. Besides, the rate of elderly people in 2045 will reach 19,64\% [11]. Based on this projection data, DIY will facing the challenge of human resources in the future.

The population ageing have two types of challange [23]. First is biological problem that maintaining optimal physical and mental conditions. The second challenge is the social, economic, and cultural issues that optimizing retirement age for better living. Researchers such as Mafauzy [24] and Christensen, Doblhammer, Rau and Vaupel [25] also agree with this opinion.

The government also have to consider those challenges in DIY. Many ways must to be prepared so that a lot of elderly resources in DIY are not a burden. Collaboration between the government, the private sector, non-governmental institutions and the community need to be optimized to prepare for the elderly who are resilient, healthy, and productive in the future.

\section{Conclusion}

The Special Region of Yogyakarta is a province that has reached the final demographic transition. It is shown by the low indicators of mortality and fertility. In addition, population ageing has been happening since 1990, and the percentage of elderly in 1990 was $11,3 \%$. Nowadays, DIY is becoming a province with an elderly population structure in Indonesia. It refers to percentage of the elderly, which more than $14 \%$ in 2019 . It is predicted that the elderly will increase in DIY in the short future. In 2045 the percentage will be $19,64 \%$. This is a challenge for the government, and many solutions need be prepared, so the elderly resources in DIY do not become a burden in the future. 
This paper is part of Hibah Dosen Mandiri Faculty of Geography, UGM entitled "The Special Region of Yogyakarta's Demographic Transition and Its Population Ageing" funded in 2020. The author would like to thank several parties including Dr. Sukamdi, Dr. Agus Joko Pitoyo, and Dr. Umi Listyaningsih, for their guidance and input during the writing.

\section{References}

1. W. I. W. Ahmad, I. K. Astina, and Budijanto. Demographic Transition and Population Ageing. Mediterranean J. of Social Sciences. 6. 3. Page 213218. Doi:10.5901/mjss.2015.v6n3s2p213. (2017)

2. W. Feng, The Future of a Demographic Overachiever: Long-Term Implications of the Demographic Transition in China Economic and Social Implications of the Demographic Transition in Lee, R.D. and Reher D.S. (eds.). Demographic Transition and Its Concequences. New York: Population Council. ISSN 1728-4457. (2011)

3. T. Paltasingh, Demographic Transition and Population Ageing: Building an Inclusive Culture. Social Change. 42. 3. Page 391-409. DOI: 10.1177/0049085712454053. (2012)

4. E.N. Arifin, and A. Ananta, The Past Three Population Censuses: A Deepening Ageing Population in Indonesia. In Charbit, Y and Pool, I (eds.). Contemporary Demographic Transformations in China, India and Indonesia. Demographic Transformation and Socio- Economic Development. 5. Page 309-324. DOI 10.1007/978-3-319-24783-0. (2016)

5. The Central Bureau of Statistics. Population of Indonesia. Results of the 1990 Population Census (Serie S2). Jakarta: Badan Pusat Statistik. (1992). In Bahasa

6. The Central Bureau of Statistics. Daerah Istimewa Yogyakarta Dalam Angka 2004. Yogyakarta: Badan Pusat Statistik Daerah Istimewa Yogyakarta. (2004). In Bahasa

7. Kirk, D. Demographis Transition Theory. Population Studies. 50 pp. 361-387. (1996)

8. M. A. F. Alfana, D. N. Aulia, dan T. P. Wahyudi, Transisi Demografi dan Epidemilogi di Daerah Istimewa Yogyakarta. Yogyakarta: Fakultas Geografi UGM. (2018). In Bahasa

9. BPS dan BKKBN. Laporan Pendahuluan Survei Demografi dan Kesehatan Indonesia (SDKI) 2017. Jakarta: Badan Pusat Statistik dan BKKBN Jakarta. (2018). In Bahasa

10. Kementrian PPN/Bappenas, BPS dan UNFPA. Proyeksi Penduduk Indonesia 2015 - 2045. Jakarta: Badan Pusat Statistik. ISBN: 978-602-438-189-9. (2018). In Bahasa
11. The Central Bureau of Statistics. Profil Kependudukan DIY Hasil SP 2010. Yogyakarta: Badan Pusat Statistik Daerah Istimewa Yogyakarta. (2011). In Bahasa

12. Wilopo, S. A. Transisi Demografi dan Pembangunan Berkelanjutan. Populasi. 6. 1. Halaman 19-37. ISSN: 0853-0262. (1995). In Bahasa

13. The Central Bureau of Statistics. Population of Indonesia. 1971 Population Census. Seri D. Jakarta: Badan Pusat Statistik. (1975). In Bahasa

14. The Central Bureau of Statistics. Population of Indonesia. Results of the 1980 population census (Serie S Number 2). Jakarta: Badan Pusat Statistik. (1983). In Bahasa

15. A. R. Omran. The Epidemiologic Transition: A Theory of the Epidemiology of Population Change. Milbank Q. Vol.83, No.4. pp. 731-757. DOI: 10.1111/j.1468-0009.2005.00398.x. (2015)

16. Dinas Kesehatan DIY. Profil Kesehatan Daerah Istimewa Yogyakarta 2017. Yogyakarta: Dinas Kesehatan DIY. (2017). In Bahasa

17. P. Dommaraju. Perspectives on Old Age in India. In Charbit, Y and Pool, I (eds.). Contemporary Demographic Transformations in China, India and Indonesia. Demographic Transformation and SocioEconomic Development . 5. Page 293-308. DOI 10.1007/978-3-319-24783-0. (2016)

18. The Central Bureau of Statistics. Statistik Penduduk Lanjut Usia Indonesia 2019. Jakarta: Badan Pusat Statistik. ISSN: 2086-1036. (2019)

19. The Central Bureau of Statistics. Daerah Istimewa Yogyakarta Dalam Angka 2020. Yogyakarta: Badan Pusat Statistik Daerah Istimewa Yogyakarta. (2020)

20. The Central Bureau of Statistics. Daerah istimewa Yogyakarta Dalam Angka 2005. Yogyakarta: Badan Pusat Statistik Daerah Istimewa Yogyakarta. (2005)

21. The Central Bureau of Statistics. Daerah istimewa Yogyakarta Dalam Angka 2016. Yogyakarta: Badan Pusat Statistik Daerah Istimewa Yogyakarta. (2016)

22. The Central Bureau of Statistics. 2015. Penduduk Provinsi Daerah Istimewa Yogyakarta Hasil Sensus Penduduk 1961-2010. Yogyakarta: Badan Pusat Statistik Daerah Istimewa Yogyakarta

23. M. Sander, B. Oxlund, A. Jespersen, A. Krasnik, E. L. Mortensen, R. G. J. Westendorp, L.J. Rasmussen. The Challenges Of Human Population Ageing, Age Ageing, 44, 2, Pp 185-187, https://doi.org/10.1093/ageing/afu189. (2015)

24. M. Mafauzy. The Problems and Challenges Of The Ageing Population Of Malaysia. Malays. J. Med. Sci.: MJMS. 7,1: 1-3. (2000)

25. Christensen, K., Doblhammer, G., Rau, R. and Vaupel J.W. Ageing populations: the challenges ahead. Lancet. 374. 9696. pp. 1196-1208. doi:10.1016/S0140-6736(09)61460-4. (2009) 